\title{
ANALISIS IMPLEMENTASI PERATURAN DAERAH NOMOR 6 TAHUN 2002 MENANGANI JUMLAH GELANDANGAN DAN PENGEMIS DI KOTA BATAM
}

\author{
Dr. Lu Sudirman ${ }^{1}$ \\ Shinta $^{2}$
}

\begin{abstract}
This research was conducted to find out the implementation of Regional Regulation Number 6 of 2002 in dealing with the problem of Homeless and Beggars. The high level of poverty is one of the main factors in the emergence of homeless and beggars, they are considered to disturb public order and the beauty of Batam City. Therefore, this problem must be surmounted immediately.

This research uses empirical research methods, where research material is obtained directly from the facts that occur in the field. Furthermore, the Writer makes comparisons of written regulations, theories, journals obtained through library materials. Then the data analysis method used is the analysis of qualitative data by developing concepts, theories, legislation and comparisons of their implementation, then connecting with the facts that occur in the field.

In this research it can be concluded that the legislation does not fully provide legal certainty if it is not supported by the correct implementation. It is very necessary for the role of law enforcement officials to overcome this problem and oversee the existence of homeless and beggars. However, supervision and guidance efforts carried out by the Social Service could not work effectively, the lack of support from the society of Batam City was also one of the obstacles. It is expected that the prevention efforts can eradicate the number of homeless and beggars so that they can improve social welfare in Batam City.
\end{abstract}

Keywords: Implementation, Homelessness and Beggars, Coaching Effort

\footnotetext{
${ }^{1}$ Fakultas Hukum Universitas Internasional Batam

${ }^{2}$ Fakultas Hukum Universitas Internasional Batam
} 


\section{A. LATAR BELAKANG}

Dengan berkembangnya zaman seiring waktu maka lebih banyak pula masalah sosial yang terbentuk di masyarakat. Masalah sosial sendiri merupakan suatu masalah yang berkaitan dengan nilai sosial maupun yang berhubungan dengan lembaga kemasyarakatan. Disebutkan sebagai masalah sosial sebab bertautan dengan gejala-gejala atau suatu kondisi yang membahayakan ketentraman didalam masyarakat itu sendiri. Indonesia merupakan salah satu di antara negara berkembang yang meghadapi permasalahan sosial dalam lingkungan masyarakatnya. Salah satu dari sekian banyaknya masalah sosial yang sedang dihadapi oleh Indonesia adalah masalah kemiskinan. Kemiskinan yang terbentuk di Indonesia, salah satunya di Kota Batam disebabkan oleh beberapa faktor antara lain adalah rendahnya pendidikan masyarakat, tidak mempunyai keterampilan tertentu, memiliki fisik maupun mental yang terbatas, dan kurangnya kemampuan untuk berusaha mencoba sesuatu, serta faktor yang paling penting adalah kurangnya lapangan pekerjaan yang tersedia di Kota Batam. Penyebab utama dari segala masalah tersebut adalah jumlah pertumbuhan penduduk yang tidak seimbang dengan jumlah lapangan kerja yang tersedia. Kemudian semakin menyempitnya lahan pertanian di desa disebabkan oleh pembangunan pemukiman, perusahaan, pabrik dan lain sebagainya. Keadaan ini menyebabkan penduduk desa yang melakukan urbanisasi dengan tekad untuk mengubah nasib, tetapi kebanyakan dari mereka tidak membekali diri dengan pendidikan dan keterampilan yang memadai sehingga akhirnya mereka tidak dapat bersaing di dunia kerja.

Badan Pusat Statistik mencatatkan bahwa jumlah pengangguran di Kota Batam pada tahun 2017 mencapai 46.574 jiwa. ${ }^{3}$ Hal ini menunjukkan bahwa jumlah penduduk di Kota Batam yang tidak bekerja terbilang banyak, Kemudian masalah ini memicu masalah sosial lainnya, yaitu munculnya keberadaan gelandangan dan pengemis atau biasa disebut dengan singkatan gepeng. Mereka termasuk salah satu kelompok masyarakat yang keberadaannya wajib memperoleh perhatian secara khusus dari Pemerintah mengenai kesejahteraan hidup dan kesehatan mereka. Setiap penduduk di Negara Kesatuan Republik Indonesia mempunyai hak untuk hidup secara adil dan sejahtera. Sangatlah sulit untuk mendapatkan pekerjaan sehingga banyak penduduk yang menganggur dan mengakibatkan semakin meningkatnya angka kemiskinan di Indonesia, Kejadian ini menyebabkan kelahiran seorang gelandangan dan pengemis. Pada umumnya orang-orang ini bertahan hidup dengan mengemis, mulai dari mengamen di jalan raya yang dengan menggunakan berbagai alat musik dan nyanyian, kemudian dengan menggunakan kemoceng untuk membersihkan kendaraan ataupun hanya meminta-minta saja dengan harapan dapat memperoleh belas kasihan dari masyarakat setempat. Mengemis umumnya dilakukan di tempat-tempat umum seperti di tempat makan, transportasi umum, lampu merah, dan bahkan dengan cara berkunjung ke rumah masyarakat. Tindakan mengemis dapat

${ }^{3}$ BPS kota Batam, "Pengangguran Perkotaan Di Kota Batam,” 2017. 
meresahkan orang lain, terutama masyarakat sekitarnya karena tidaklah semua pengemis itu bertingkah laku sopan dan baik.

Pada Peraturan Daerah Kota Batam Nomor 6 Tahun 2002 tentang Ketertiban Sosial Pasal 5 ayat (4) dan (5) dengan tegas telah menyebutkan bahwa: ${ }^{4}$ Setiap orang atau badan yang berada dan atau berdomisili di Kota Batam dilarang: melakukan usaha penampungan, penyaluran dan perbuatan sebagai pengemis dan melakukan perbuatan sebagai gelandangan

Berdasarkan Pasal yang Peneliti sebutkan diatas, dapat dilihat bahwa Kota Batam merupakan Kota yang telah diperuntukkan untuk bebas dari para gelandangan dan pengemis. Kemudian larangan menggelandang dan mengemis juga dapat ditemukan dalam Kitab Undang-Undang Hukum Pidana sebagai berikut: ${ }^{5}$

Pasal 504

(1) Barang siapa mengemis di muka umum, diancam karena melakukan pengemisan dengan pidana kurungan paling lama enam minggu.

(2) Pengemisan yang dilakukan oleh tiga orang atau lebih, yang berumur di atas enam belas tahun, diancam dengan pidana kurungan paling lama tiga bulan.

\section{Pasal 505}

(1) Barang siapa bergelandangan tanpa pencarian, diancam karena melakukan pergelandangan dengan pidana kurungan paling lama tiga bulan.

(2) Pergelandangan yang dilakukan oleh tiga orang atau lebih, yang berumur di atas enam belas tahun diancam dengan pidana kurungan paling lama enam bulan.

Dilihat dari pernyataan di atas, sudah jelas bahwa tindakan mengemis adalah tindakan yang melanggar peraturan. Tetapi hal tersebut malah semakin tidak terkontrol dan jumlah gelandangan dan pengemis pun relatif banyak. Sangat diperlukan upaya penanggulangan dari Pemerintah dan para aparat penegak hukum untuk mengatasi masalah ini dan mengawasi keberadaan gelandangan dan pengemis di Indonesia khususnya Kota Batam.

Berdasarkan latar belakang yang Peneliti uraikan diatas, maka Peneliti tertarik untuk melakukan sebuah penelitian dengan judul "Analisis Implementasi Peraturan Daerah Nomor 6 Tahun 2002 Tentang Ketertiban Sosial Dalam Menangani Jumlah Gelandangan dan Pengemis di Kota Batam".

\footnotetext{
${ }^{4}$ Peraturan Daerah Nomor 6 Tahun 2002 tentang Ketertiban Sosial, Pasal 5

${ }^{5}$ Kitab Undang-Undang Hukum Pidana
} 
Adapun rumusan masalah dalam penelitian ini adalah:

1. Apakah implementasi dari Peraturan Daerah Nomor 6 Tahun 2002 tentang Ketertiban Sosial mengenai gelandangan dan pengemis di Kota Batam sudah terlaksana dengan baik?

2. Apasajakah faktor-faktor yang menyebabkan keberadaan gelandangan dan pengemis di Kota Batam?

3. Bagaimana upaya yang dilakukan oleh Dinas Sosial dalam menanggulangi masalah gelandangan dan pengemis di Kota Batam?

Penelitian ini bertujuan untuk:

1. Untuk mengetahui keefektivitas dari implementasi Peraturan Daerah Nomor 6 Tahun 2002 tentang Ketertiban Sosial dalam menangani jumlah gelandangan dan pengemis di Kota Batam.

2. Untuk mengidentifikasi faktor yang menjadi penyebab keberadaan gelandangan dan pengemis di Kota Batam.

3. Untuk mengetahui upaya yang dilakukan oleh Dinas Sosial dalam hal meminimalisir keberadaan gelandangan dan pengemis di Kota Batam.

\section{B. METODE PENELITIAN}

Pada penelitian ini, Peneliti menggunakan metode penelitian empiris dan normatif, dimana metode ini berfungsi untuk melihat implementasi ketentuan hukum normatif dalam aksinya pada setiap peristiwa hukum yang terjadi di dalam masyarakat. Adapun bahan penelitian didapatkan oleh Peneliti secara langsung dari fakta-fakta yang terjadi di lapangan.

Selanjutnya Peneliti membandingkannya dengan peraturan tertulis yang sudah ada. ${ }^{6}$ Latar belakang Peneliti memilih jenis penelitian ini ialah rumusan masalah pada judul skripsi ini dapat dikaji langsung dengan menggunakan studi lapangan beserta dengan peraturan peraturan yang telah ada.

Dalam penelitian ini, Peneliti akan menggunakan teknik library research dan didukung dengan teknik studi lapangan karena penelitian ini menggunakan penelitian normatif-empiris. Dimana Peneliti akan mengumpulkan seluruh bahan hukum primer, sekunder dan tersier dan mengolahnya menjadi suatu pernyataan. Kemudian Peneliti juga akan melakukan penelitian secara langsung dilapangan, yaitu dengan melakukan wawancara terhadap Bapak Akhmad Yani, yang menjabat sebagai Seksi Rehabilitasi Tuna Sosial dan Korban Perdagangan Orang di Kantor Dinas Sosial Kota Batam. Dan Peneliti juga akan melakukan observasi secara langsung dan membagikan kuesioner kepada 100 responden mengenai penilaian responden terhadap tingkat kenyamanan atas keberadaan gelandangan dan pengemis di Kota Batam. Dalam

6 "Metode Penelitian Hukum Empiris Dan Normatif," accessed March 20, 2019, https://idtesis.com/metode-penelitian-hukum-empiris-dan-normatif/. 
penelitian ini, Peneliti akan menggunakan metode analisis data yang bersifat metode kualitatif. Penelitian ini dengan cara mengukur kualitas data yang tersedia, kemudian diseleksi terlebih dahulu dan dihubungkan dengan pembahasan yang ingin dianalisa. Data kualitatif diperoleh dengan mengembangkan konsep-konsep, perundangundangan serta teori-teori. Peneliti lebih banyak menggunakan perspektif secara subjektif atas hasil seleksi kualitas data yang digunakan. Hasil seleksi dimanfaatkan sedemikian rupa untuk mencapai hasil yang penyusunan ilmiah yang baik dan benar.

\section{HASIL PENELITIAN DAN PEMBAHASAN}

Dalam penelitian ini, Peneliti melakukan wawancara secara langsung ke Kantor Dinas Sosial. Menurut Akhmad Yani, S.ST yang menjabat selama 2 tahun sebagai Seksi Rehabilitasi Tuna Sosial Dan Korban Perdagangan Orang bahwa keberadaan gelandangan dan pengemis di Kota Batam itu sulit untuk diatasi. Walaupun jumlah mereka mengalami penurunan setiap tahunnya, tetapi angka dari jumlah mereka tersebut tetap terbilang banyak. Menurutnya, Peraturan Daerah Nomor 6 Tahun 2002 di Kota Batam itu sudah efektif, tetapi masalah pengawasannya terbentur oleh dana operasional. Salah satu kendala utama yang dialami oleh pihak Dinas Sosial adalah tidak adanya panti rehabilitasi yang dikhususkan untuk melatih para gelandangan dan pengemis saja. Dinilainya pelatihan yang diberikan oleh Unit Pelaksana Teknis (UPT) Panti Rehabilitasi Sosial Nilam Suri tidak secara khusus sehingga terkesan kurang maksimal. Gelandangan dan pengemis yang terjaring dan mengikuti pembinaan dan pelatihan di Panti Rehabilitasi Sosial Nilam Suri, mayoritasnya tidak membuahkan hasil yang baik dari kegiatan pelatihan tersebut, dan kebanyakan dari mereka kembali turun ke jalanan. ${ }^{8}$

UPT Panti Rehabilitasi Sosial Nilam Suri merupakan tempat bimbingan yang dikelola oleh Dinas Sosial Kota Batam yang berfungsi memberikan pengetahuan dan melatih keterampilan bagi Penyandang Masalah Kesejahteraan Sosial (PMKS), seperti anak jalanan, putus sekolah, penyandang cacat, gelandangan dan pengemis dan lain sebagainya. Panti Nilam Suri memberikan kegiatan pelatihan diantaranya seperti pelatihan pengelasan dasar, sablon, bengkel, dan kegiatan menjahit bagi perempuan, hal ini dilakukan untuk meningkatkan keterampilan yang ada pada diri para peserta, dan juga untuk pemulihan kesadaran, meningkatkan rasa percaya diri dan tanggung jawab yang ada dalam diri mereka.

Kemudian kurangnya peran yang dilakukan oleh masyarakat dalam mendukung Peraturan Daerah inilah yang menjadi masalah. Kebanyakan masyarakat Kota Batam tidak mengetahui atau bahkan mengabaikan fakta bahwa keberadaan gelandangan dan pengemis itu melanggar peraturan

\footnotetext{
7 "Teknik Pengumpulan Data Dan Analisis Dalam Penelitian Fatkhan.web.id," accessed March 20, 2019, https://fatkhan.web.id/teknik-pengumpulan-data-dan-analisis-dalam-penelitian/.

${ }^{8}$ Hasil wawancara dengan Akhmad Yani, S.ST, Seksi Rehabilitasi Tuna Sosial Dan Korban Perdagangan Orang, 29 November 2018.
} 
perundang-undangan yang berlaku, karena munculnya rasa iba terhadap mereka sehingga masyarakat cenderung memberikan mereka bantuan berupa uang ataupun makanan. Bantuan dari masyarakat inilah yang membuat eksistensi gelandangan dan pengemis tetap bertahan sampai saat ini. Diyakini apabila "tidak ada yang memberi" maka "tidak akan muncul gelandangan dan pengemis", bantuan yang mereka dapatkan dari masyarakat secara cuma-cuma malah membentuk sifat yang malas pada diri mereka. Memberantas atau meminimalisir keberadaan gelandangan dan pengemis di Kota Batam ini memang sulit dilakukan apabila tidak didukung dengan peran masyarakat Kota Batam. Tetapi untuk pihak yang bertanggungjawab dan berwenang dalam hal ini diharapkan terlebih dahulu mengedepankan aksinya di lapangan.

\section{Implementasi dari Peraturan Daerah Kota Batam Nomor 6 Tahun 2002 tentang Ketertiban Sosial dalam Menangani Jumlah Gelandangan dan Pengemis di Kota Batam}

Gelandangan dan pengemis dianggap tidak sesuai dengan norma kehidupan bangsa Indonesia yang berdasarkan Pancasila dan UndangUndang Dasar 1945. Larangan untuk menggelandang dan mengemis diatur dalam Pasal 504 dan Pasal 505 Kitab Undang-Undang Hukum Pidana ("KUHP"), Buku ke-3 tentang Tindak Pidana Pelanggaran yang berbunyi:

\section{Pasal 504 KUHP}

(1) Barang siapa mengemis di muka umum, diancam karena melakukan pengemisan dengan pidana kurungan paling lama enam minggu.

(2) Pengemisan yang dilakukan oleh tiga orang atau lebih, yang berumur di atas enam belas tahun, diancam dengan pidana kurungan paling lama tiga bulan.

\section{Pasal 505 KUHP}

(1) Barang siapa bergelandangan tanpa pencarian, diancam karena melakukan pergelandangan dengan pidana kurungan paling lama tiga bulan.

(2) Pergelandangan yang dilakukan oleh tiga orang atau lebih, yang berumur di atas enam belas tahun diancam dengan pidana kurungan paling lama enam bulan.

Untuk wilayah Kota Batam, larangan menggelandang dan mengemis juga diatur lebih lanjut di dalam Peraturan Daerah Kota Batam Nomor 6 Tahun 2002 tentang Ketertiban Sosial.

Melalui wawancara yang dilakukan oleh Peneliti terhadap Akhmad Yani, dapat diketahui bahwa dalam menangani keberadaan gelandangan dan pengemis, Dinas Sosial Kota Batam telah melakukan beberapa pendekatan melalui pencegahan, pembinaan dan rehabilitasi sosial. Dalam menangani masalah gelandangan dan pengemis, Dinas Sosial Kota Batam khusus menyediakan Petugas 
Tim Penjangkauan yang biasanya dikenal dengan Tim Razia untuk melakukan penjangkauan di tempat umum secara berskala. Biasanya razia dilakukan atas Surat Perintah Tugas dari Kepala Dinas Sosial Kota Batam, kemudian dilakukan dibawah pengawasan dari 2 orang tim Dinas Sosial sebanyak 5 (lima) kali dalam 1 (satu) bulan. Penjangkaun secara besar-besaran serta menyeluruh sampai ke pelosok-pelosok juga dilakukan oleh Tim Razia dari Dinas Sosial dan Satuan Polisi Pamong Praja sebanyak 2 (dua) kali dalam 1 (satu) tahun.

Eksistensi dari gelandangan dan pengemis memang tidak dapat dihindari dengan mudah oleh Negara Indonesia, sebab akar dari permasalahan ini adalah kemiskinan. Dinas Sosial Kepulauan Riau menyebutkan bahwa Kota Batam merupakan penyumbang terbesar angka kemiskinan, diikuti dengan semakin banyaknya pendatang dari luar yang mengadu nasib sehingga meningkatkan angka pengangguran Kota Batam di tahun 2017 sebanyak 46.574 orang.

Tabel 1.1

Jumlah Gelandangan dan Pengemisdi Kota Batam Pada Tahun 2014, 2016, dan 2017

\begin{tabular}{|c|c|c|c|}
\hline No & Tahun & $\begin{array}{c}\text { Jumlah Gelandangan } \\
\text { Yang terjaring }\end{array}$ & $\begin{array}{c}\text { Jumlah Pengemis } \\
\text { Yang terjaring }\end{array}$ \\
\hline 1 & 2014 & 384 & 266 \\
\hline 2 & 2016 & 273 & 306 \\
\hline 3 & 2017 & 268 & 133 \\
\hline \multicolumn{4}{|c|}{ Sumber: Dinas Sosial Kota Batam. }
\end{tabular}

Tabel 1.2

Tempat Asal Gelandangan dan Pengemis di Kota Batam

\begin{tabular}{|c|c|c|c|}
\hline No. & Tahun & Asal & Jumlah \\
\hline \multirow{2}{*}{1.} & \multirow{2}{*}{2014} & Kota Batam & 148 \\
\cline { 3 - 4 } 2. & \multirow{2}{*}{2016} & Luar Kota & 502 \\
\cline { 3 - 4 } & & Kota Batam & 66 \\
\hline \multirow{2}{*}{3.} & \multirow{2}{*}{2017} & Kota Batam & 115 \\
\cline { 3 - 4 } & & Luar Kota & 286 \\
\hline \multirow{2}{*}{4.} & \multirow{2}{*}{ Total } & Kota Batam & 329 \\
\cline { 3 - 4 } & & Luar Kota & 1301 \\
\hline
\end{tabular}

Sumber: Dinas Sosial Kota Batam.

Dapat dilihat dari tabel 1.1 dan tabel 1.2, maka dapat ditarik kesimpulan bahwa mayoritas gelandangan dan pengemis di Kota Batam sebesar $80 \%$ berasal dari luar Kota Batam. Menurut Kepala Dinas Ketenagakerjaan Kota Batam, meningkatnya angka pengangguran ini dipengaruhi oleh tingginya angka pendatang setiap waktu sehingga para pencari kerja yang tidak memiliki skill tidak akan mampu bersaing di dunia industri. Hal ini menyebabkan semakin tingginya angka pengangguran sehingga jumlah keberadaan gelandangan dan pengemis yang berasal dari luar pun semakin 
meningkat.

Berdasarkan tabel diatas yang menunjukkan bahwa jumlah gelandangan dan pengemis di Kota Batam pada tahun 2014 sebanyak 650 orang, kemudian pada tahun 2016 sebanyak 579 orang dan pada tahun 2017 sebanyak 401 orang yang terjaring razia. Walaupun jumlah gelandangan dan pengemis setiap tahunnya mengalami penurunan, tetapi angka dari jumlah mereka tetap terbilang besar. Sehingga Peneliti merasa bahwa implementasi dari Peraturan Daerah mengenai Ketertiban Sosial yang berlaku di Kota Batam itu tidak berjalan secara maksimal. Disini Peneliti mengetahui bahwa terdapat beberapa hambatan yang dialami oleh Dinas Sosial dalam mengimplementasikan peraturan daerah ini, sehingga pengawasan dari pihak terkait itu menjadi tidaklah efektif. Tanpa implementasi yang efektif maka peraturan daerah yang dibentuk pun tidak akan terlaksana dengan baik.

Sesuai dengan Teori Efektivitas yang disebutkan oleh Soerjono Soekanto, Peneliti menguraikan secara satu-persatu faktor yang menyebabkan bahwa kurang efektifnya implementasi dari Peraturan Daerah Kota Batam Nomor 6 Tahun 2002 tentang Ketertiban Sosial sebagai berikut:

a. Faktor dari hukum itu sendiri (undang-undang).

Hasil Penelitian yang didapatkan oleh Peneliti menyatakan bahwa Peraturan Daerah Kota Batam Nomor 6 Tahun 2002 tentang Ketertiban Sosial dinyatakan tidak dapat terlaksana dengan baik sebab setiap pasal yang mengatur mengenai gelandangan dan pengemis itu tidak terlalu mengupas secara menyeluruh karena terlalu umum. Adapun sanksi pidana yang telah diatur dalam Peratuan Daerah Kota Batam dan Peraturan Perundang-undangan lainnya itu tidak diberlakukan terhadap para gelandangan dan pengemis, karena aparat penegak hukum cenderung tidak tegas dalam menjalankan tugasnya. Ketentuan hukum pidana tetap diperlukan dalam rangka menanggulangi masalah gelandangan dan pengemis di Kota Batam. Dengan adanya ketentuan pidana tersebut yang sesuai dengan fungsi hukum sebagai sarana untuk mengatur dan membina masyarakat, maka hal tersebut seharusnya dapat memengaruhi pola perilaku masyarakat dan mengarahkan masyakat untuk tidak melakukan perbuatan gelandangan dan pengemis. Tetapi perlu dibedakan antara gelandangan dan pengemis yang memang melakukan perbuatan tersebut karena kondisi yang terpaksa (faktor ekonomi, kesusahan mendapatkan pekerjaan) dengan gelandangan dan pengemis yang meminta-minta secara sengaja (pengemis yang teroganisir, pengemis musiman). Sanksi pidana pun perlu diterapkan kepada orang-orang yang melakukan perbuatan menggelandang dan mengemis yang telah terorganisir. Umumnya mereka secara sengaja melakukan 
perbuatan menggelandang dan mengemis dengan bantuan dari seseorang yang sudah dianggap sebagai bos penolong, dengan maksud untuk memperoleh keuntungan dari masyarakat setempat. Oleh karena itu, sanksi pidana tetap harus tegas diterapkan kepada mereka yang dengan sengaja melakukan perbuatan menggelandang dan mengemis padahal mereka merupakan orang yang berkecukupan.

b. Faktor penegak hukum, yakni pihak-pihak yang membentuk maupun menerapkan hukum.

Menurut Peneliti, para penegak hukum tidak melakukan pengawasan sesuai dengan Peraturan yang berlaku sebaikbaiknya. Pengawasan yang dilakukan baik oleh Pemerintah, Dinas Sosial Kota Batam dan Satuan Polisi Pamong Praja dan pihak terkait lainnya dilakukan secara tidak maksimal. Sesuai dengan hasil Penelitian, Peneliti mengetahui bahwa razia dilakukan sebanyak 5 (lima) kali dalam 1 (satu) bulan. Tindakan berupa razia tersebut Peneliti anggap sangat kurang optimal karena keberadaan gelandangan dan pengemis tiada habisnya, seharusnya pihak penegak hukum menggencarkan aksi razianya sehingga para gelandangan dan pengemis dijalan ini takut untuk kembali ke jalan. Berdasarkan observasi yang dilakukan oleh Peneliti secara pribadi, Peneliti menyadari bahwa gelandangan dan pengemis yang berada di jalan umum Kota Batam khususnya di beberapa lampu merah merupakan sosok orang yang sama setiap harinya. Disini Peneliti merasa janggal akan hal itu, apakah sosok mereka lolos setiap kali pihak Dinas Sosial melakukan razia? Atau setelah ditangkap mereka kembali lagi ke jalan? Jadi, Peneliti merasa para penegak hukum tidak menjalankan tugasnya semaksimal mungkin. Bahkan Anggota Komisis IV DPRD Kota Batam Udin P Sihaloho menilai Dinas Sosial Kota Batam tidak serius menangani masalah gelandangan dan pengemis di Kota Batam. ${ }^{9}$

c. Faktor sarana atau fasilitas yang mendukung penegakan hukum.

Melalui wawancara yang dilakukan oleh Peneliti dengan salah satu anggota dari pihak Dinas Sosial Kota Batam, Peneliti mengetahui bahwa kendala terbesar penanganan gelandangan dan pengemis adalah masalah dana operasional. Tidak adanya tempat rehabilitasi khusus untuk gelandangan dan pengemis juga menjadi salah satu hambatan. Panti rehabilitasi Nilam Suri digunakan sebagai pusat rehabilitasi bagi para Penyandang Masalah Kesejahteraan Sosial di Kota Batam. Sayangnya, Gedung Pusat Rehabilitasi Sosial Nilam Suri ini hanya

\footnotetext{
9 "DPRD Batam Sorot Penanganan Gepeng Tak Serius, Kini Pengemis Mulai Marak Di Beberapa Lampu Merah - Tribun Batam," accessed January 21, 2019, http://batam.tribunnews.com/2019/01/18/dprd-batam-sorot-penanganan-gepeng-tak-serius-kinipengemis-mulai-marak-di-beberapa-lampu-merah.
} 
beroperasi sekali dalam setahun. Sisanya, ia mati suri. Hal ini disebabkan oleh minimnya dana yang dianggarkan untuk panti tersebut sehingga menjadi kendala yang cukup menghambat kegiatan. Bahkan tidak ada dana operasional tersendiri yang dianggarkan untuk panti tersebut, anggaran yang ada masih menyatu dengan anggaran Dinas Sosial. Peneliti juga mengetahui bahwa dana untuk mengadakan suatu pelatihan itu besar, sehingga minimnya dana untuk melakukan pelatihan menyebabkan pelatihan yang diadakan menjadi kurang maksimal.

d. Faktor masyarakat, yakni lingkungan dimana hukum tersebut berlaku atau diterapkan.

Sebagian masyarakat Kota Batam masih tidak memedulikan kenyataan bahwa keberadaan gelandangan dan pengemis itu dilarang oleh Pemerintah. Masih saja ada masyarakat yang merasa iba dan memberikan bantuan kepada mereka. Disini Peneliti tidak menegaskan bahwa kita sebagai masyarakat sosial tidak boleh membantu sesama, tetapi bentuk bantuan yang diberikan oleh masyarakat kepada gelandangan dan pengemis yang biasanya berupa uang itu malah memberikan dampak yang negatif kepada mereka. Pemberian bantuan dari masyarakat Kota Batam membentuk sifat yang malas pada diri mereka, sehingga mereka akan berfikir bahwa tanpa bekerja pun bisa menghasilkan uang dengan mengharapkan belas kasihan dari masyarakat Kota Batam. Diharapkan semua masyarakat Indonesia khususnya masyarakat Kota Batam dapat mendukung Peraturan Daerah ini dengan tidak memberikan uang kepada gelandangan dan pengemis yang berada di jalan umum sehingga keberadaan mereka dapat berkurang atau bahkan hilang. Peran dari masyarakat sangatlah penting, Pemerintah juga telah memasang papan kecil di sekitar jalan khususnya di lampu merah agar dapat mengingatkan masyarakat bahwa Kota Batam adalah kawasan bebas dari gelandangan dan pengemis menurut peraturan yang telah di atur dalam Peraturan Daerah Kota Batam Nomor 6 Tahun 2002 tentang Ketertiban Sosial. Masyarakat yang berkehendak untuk membantu orang yang tidak mampu dapat menyalurkan bantuannya melalui panti-panti sosial yang ada.

Peneliti juga menggunakan teori Hak Asasi Manusia untuk mendukung penelitian ini. Menurut Teori Hak Asasi Manusia, hubungan antara hak asasi manusia dengan negara hukum sangat erat. "Hak asasi mausia adalah hak dasar atau kewarganegaraan yang melekat pada individu sejak ia lahir secara kodrat yang diberikan langsung oleh Tuhan Yang Maha Esa yang tidak dapat dirampas dan dicabut keberadaannya dan wajib dihormati, dijunjung tinggi, dan dilindungi oleh negara, hukum, pemerintah dan setiap orang demi kehormatan dan 
perlindungan harkat dan martabat manusia." Dalam penegakan hak asasi manusia harus dilandasi oleh aturan hukum, yaitu aturan perundang-undangan. Pemerintah dalam menegakan hak asasi manusia di negara yang berasaskan hukum, harus selalu memperhatikan peraturan-peraturan yang berlaku. Ahli hukum Eropa Kontinental, antara lain Immanuel Kant dan Stahl menyebutkan adanya pengakuan hak asasi manusia sebagai salah satu unsur dari negara hukum. Hal ini menjelaskan bahwa negara mempunyai kewajiban untuk melindungi setiap hak asasi manusia yang dimiliki oleh warga negaranya. Hak-hak gelandangan dan pengemis juga tidak terlepas dari kewajiban negara. Sesuai dengan Undang-Undang Dasar 1945 Pasal 27 ayat 2 yang menyebutkan "Tiap-tiap warga negara berhak atas pekerjaan dan penghidupan yang layak." Kemudian Pasal 34 ayat (1) yang berbunyi: "Fakir miskin dan anak-anak terlantar dipelihara oleh negara.". Hak-hak dasar tersebut yang telah dituangkan dalam peraturan perundang-undangan dinyatakan tidak terealisasikan dengan baik. Masih banyak masyarakat Indonesia yang tidak memiliki kehidupan yang layak sesuai dengan martabat manusia. Adapun masyarakat yang hidup di bawah garis kemiskinan yang tidak mendapatkan jaminan sosial, padahal telah diatur dalam peraturan tertulis bahwa setiap orang berhak atas pelayanan kesehatan. Peneliti mengetahui bahwa sebagian besar para gelandangan dan pengemis di Kota Batam tidak terdata dalam peserta program jaminan sosial. Padahal sesuai dengan Undang-Undang Nomor 24 Tahun 2011 tentang Badan Penyelenggara Jaminan Sosial, Pasal 1 angka 7 menyebutkan definisi bantuan iuran sebagai berikut, "Bantuan Iuran adalah Iuran yang dibayar oleh Pemerintah bagi fakir miskin dan orang tidak mampu sebagai Peserta program Jaminan Sosial"

Hal ini disebabkan oleh kurang maksimalnya penjangkauan yang diadakan oleh para aparat penegak hukum sehingga masih banyak fakir miskin dan orang tidak mampu yang tidak terdaftar sebagai peserta program jaminan sosial. Minimnya pengetahuan dari para fakir miskin termasuk gelandangan dan pengemis di Kota Batam juga menjadi salah satu alasan mereka tidak mendapatkan hak-hak mereka yang seharusnya dilindungi oleh negara.

Berdasarkan pemaparan dan penjelasan yang telah diuraikan diatas, Peneliti menyatakan bahwa implementasi dari Peraturan Daerah Kota Batam Nomor 6 Tahun 2002 tentang Ketertiban Sosial di Kota Batam dalam menangani jumlah gelandangan dan pengemis di Kota Batam dinyatakan kurang efektif. 


\section{Faktor Penyebab Keberadaan Gelandangan dan Pengemis di Kota Batam}

Keberadaan gelandangan dan pengemis tidak diinginkan oleh masyarakat dikarenakan dianggap mengganggu ketertiban umum dan keindahan Kota Batam. Keberadaan mereka disebut sebagai salah satu penyakit sosial atau penyakit masyarakat. Segala bentuk tingkah laku yang dianggap tidak sesuai, melanggar nilai-nilai, norma umum, hukum formal, adat istiadat, atau tidak bisa diintegrasikan dalam pola tingkah laku umum dinyatakan sebagai suatu penyakit sosial. Kehidupan gelandangan dan pengemis serba terbatas, biasanya mereka hidup bergantung pada belas kasihan dan pemberian dari orang lain, dengan berkeliaran di tempat atau jalanjalan umum sehingga keberadannya dalam kehidupan masyarakat dirasa sangat mengganggu dan meresahkan Kota Batam.

Secara umum Peneliti menemukan beberapa faktor yang memengaruhi atau menyebabkan seseorang menjadi gelandangan dan pengemis, yakni:

\section{a. Faktor Ekonomi}

Faktor ekonomi sangat berperan penting dalam mobilitas sosial. Seseorang dengan kondisi ekonomi yang baik dapat dengan mudah mengakses proses yang membantu mobilitas sosialnya, terutama dalam hal pendidikan. Dengan kondisi ekonomi yang baik, seseorang dapat meraih pendidikan yang tinggi, sehingga ia memperoleh ilmu pengetahuan, kemampuan dan keterampilan yang akan sangat membantu ia dalam dunia kerja. Dengan ini ia akan mudah melakukan mobilitas sosial karena posisinya dalam masyarakat akan naik sebab ia memiliki pekerjaan dan penghasilan yang tinggi. Sebaliknya, orang dengan kondisi ekonomi yang buruk akan sulit untuk menempuh pendidikan sehingga ia akan sulit untuk bersaing dalam dunia kerja dan tidak bisa memperbaiki mobilitas sosialnya. Sama halnya dengan gelandangan dan pengemis yang tidak memiliki kondisi ekonomi yang baik sehingga mereka pun sulit untuk menempuh pendidikan yang layak dan mereka akan terus berada pada posisi yang sama bila tidak ada upaya yang dilakukan oleh mereka maupun negara. Jadi, meningkatnya jumlah penyandang masalah kesejahteraan sosial termasuk gelandangan dan pengemis diakibatkan oleh tuntutan faktor ekonomi yang semakin tinggi dan mahal dalam memenuhi kebutuhan hidup. ${ }^{10}$

\footnotetext{
10 "Faktor Ekonomi Jadi Alasan PMKS Meningkat - Heibogor.com," accessed February 23, 2019, http://www.heibogor.com/post/detail/47515/faktor-ekonomi-jadi-alasan-pmks-meningkat/.
} 


\section{b. Faktor Pendidikan}

Rendahnya tingkat pendidikan dapat menjadi kendala seseorang untuk memperoleh pekerjaan yang layak. Banyaknya para pesaing untuk memperoleh suatu pekerjaan yang layak, mengakibatkan syarat bekerja pun semakin meningkat. Pendidikan sangat berpengaruh terhadap persaingan di dunia kerja, oleh sebab itu pendidikan yang terlampau rendah dapat menimbulkan kemiskinan. ${ }^{11}$

\section{c. Faktor Urbanisasi}

Kemajuan industri yang ditandai dengan tersedianya lapangan kerja akan meningkatkan arus migrasi di Kota Batam. Tingginya arus urbanisasi menimbulkan permasalahan karena semakin sempitnya lapangan kerja menyebabkan sebagian masyarakat yang tidak mampu bersaing menjadi menganggur. Dinas Ketenagakerjaan Kota Batam mencatat sepanjang tahun 2018, ada sekitar 25 ribu pencari kerja yang berasal dari luar Batam. ${ }^{12}$ Untuk kasus gelandangan dan pengemis, ada sebagian kelompok orang itu sengaja datang ke Kota Batam dengan tujuan awal yaitu mengemis. Hal ini dapat ditemukan didalam tipe pengemis sebagai berikut:

1) Pengemis musiman, yang artinya jumlah pengemis akan bertambah pesat di saat menjelang hari-hari besar misalnya menjelang dan saat bulan ramadhan, idul fitri dan tahun baru. Kebanyakan dari mereka merupakan orang-orang yang berasal dari luar dan akan kembali ke tempat asalnya jika telah mengumpulkan uang yang diharapkannya. Sehingga tidak menutup kemungkinan bahwa perubahan status dari yang pengemis sementara menjadi pengemis permanen.

2) Pengemis yang terkoordinasi dalam suatu sindikat. Biasanya ada seseorang yang sudah dianggap sebagai bos penolong, seterusnya setiap anggota pengemis setia mengemis di jalanan dan menyetor sebagian dari hasil mengemisnya kepada bos penolongnya. Adanya perwilayahan yang sudah ditetapkan dengan anggotaanggota tersendiri.

\section{d. Adanya Keterbatasan Fisik}

Fakta lain yang Peneliti dapatkan langsung di lapangan, bahwa hampir sebagian gelandangan dan pengemis di Kota

\footnotetext{
${ }^{11}$ Hartomo, Arnicun, 2001, Ilmu Sosial Dasar, PT.Bumi Angkasa, Jakarta, hlm 329.

12 "Jumlah Pencari Kerja Asal Luar Batam Ternyata Banyak, Jumlahnya Mencapai 25 Ribu Lebih - Tribun Batam,” accessed February 21, 2019, http://batam.tribunnews.com/2018/09/18/jumlahpencari-kerja-asal-luar-batam-ternyata-banyak-jumlahnya-mencapai-25-ribu-lebih.
} 
Batam itu merupakan orang yang sudah berlanjut usia, tuna netra dan orang-orang yang memiliki cacat fisik. Masyarakat yang memiliki keterbatasan fisik akan sulit untuk memperoleh suatu pekerjaan, akhirnya mereka memilih untuk menggelandang dan mengemis di tempat umum untuk mendapatkan belas kasihan dari masyarakat setempat. Berdasarkan wawancara dengan pihak Dinas Sosial yang mengatakan bahwa gelandangan dan pengemis yang sudah lanjut usia, tuna netra dan cacat fisik lainnya itu tidak dibina melainkan dikembalikan kepada keluarganya. Kelonggaran semacam inilah yang menyebabkan para gelandang dan pengemis tersebut tidak takut dan kembali ke jalan.

e. Faktor Sosial Budaya

Faktor sosial budaya disebabkan oleh lingkungan sekitar dan para pemberi sedekah. Terdapat beberapa faktor sosial budaya yang mempengaruhi seseorang menjadi gelandangan dan pengemis, diantaranya terdiri dari: ${ }^{13}$

1) Rendahnya harga diri pada sekelompok orang mengakibatkan tidak dimilikinya rasa malu untuk memintaminta.

2) Sikap pasrah pada nasib, menganggap bahwa kemiskinan dan kondisi mereka sebagai gelandangan dan pengemis adalah nasib, sehingga tidak ada kemauan untuk melakukan suatu perubahan.

3) Kebebasan dan kesenangan hidup menggelandang, ada kenikmatan tersendiri bagi sebagian besar gelandangan dan pengemis yang hidup menggelandang, karena mereka merasa tidak terikat oleh aturan atau norma apapun.

4) Adanya sifat malas dalam diri mereka. Mulanya mengemis karena unsur kelangkaan aset ekonomi. Namun setelah beberapa tahun walau sudah memiliki aset produksi atau simpanan bahkan rumah dan tanah dari hasil mengemis tetapi mereka tetap saja mengemis. Jadi alasan mengemis karena tidak memiliki aset atau ketidakberdayaan ekonomi, untuk tipe pengemis ini tidak berlaku lagi. Sang pengemis sudah merasa keenakan. Tanpa rasa malu dan tanpa beban moril di depan masyarakat.

\footnotetext{
${ }^{13}$ Direktorat Pelayanan dan Rehabilitasi Sosial Tuna Sosila, 2005, Standar Pelayanan Minimal Pelayanan dan Rehabilitasi Sosial Gelandangan dan pengemis, Depsos RI, Jakarta. hlm.7-8.
} 


\section{Upaya Dari Dinas Sosial Dalam Menanggulangi Masalah Gelandangan dan Pengemis di Kota Batam}

Angka dari jumlah gelandangan dan pengemis di Kota Batam harus segera diatasi. Dalam memberantas masalah gelandangan dan pengemis dibutuhkan peran aktif dari para penegak hukum serta dukungan dari masyarakat terkait. Adapun langkah-langkah upaya yang dilakukan oleh pihak Dinas Sosial sebagai berikut:

a. Membentuk Tim Pelaksanaan Penjangkauan

Tim Pelaksanaan Penjangkauan dibentuk untuk menjangkau Penyandang Masalah Kesejahteraan Sosial. Tim ini dibentuk berdasarkan Surat Perintah Tugas yang dikeluarkan oleh Kepala Dinas Sosial, terdiri dari 10 (sepuluh) orang. Yang menangani khusus para gelandangan dan pengemis adalah sebanyak 2 (dua) orang.

b. Melakukan razia secara berskala

Untuk jadwal razia yang dilakukan oleh Dinas Sosial yaitu 1 bulan sebanyak 5 (lima) kali. Adapun razia yang dilakukan oleh Dinas Sosial bersama dengan Satuan Polisi Pamong Praja secara besar-besaran sebanyak 2 (dua) kali dalam setahun.

c. Ditangkap dan dibawa ke shelter

Para gelandangan dan pengemis yang terjaring dalam razia, akan ditangkap kemudian dibawa ke shelter yang bertempat di Kantor Dinas Sosial Kota Batam, Jl. Raja Ali Haji Sekupang No.9, Sungai Harapan, Sekupang, Kota Batam, Kepulauan Riau 29425.

\section{d. Identifikasi}

Hal utama yang dapat diketahui disini adalah asal daerah dari para gelandangan dan pengemis. Apabila mereka berasal dari luar maka bagian Perlindungan Jaminan Sosial bertugas untuk memulangkan mereka.

e. Pembinaan di Rumah Aman

Bagi yang terjaring dalam razia, setelah proses pemeriksaan dan pendataan maka mereka akan di tampung di tempat perlindungan aman atau biasa yang sering disebut dengan rumah aman. Pembinaan dirumah aman meliputi nasehat yang akan diberikan oleh pihak Dinas Sosial kepada para gelandangan dan pengemis yang terjaring. Mereka harus sadar dan jera terhadap perbuatan yang dilakukan mereka sebab perbuatan menggelandang dan mengemis adalah perbuatan 
yang dilarang. Dalam hal ini Dinas Sosial akan mengevaluasi para gelandangan dan pengemis, karena gelandangan dan pengemis yang produktiflah yang akan dibina selanjutnya. Mereka yang sudah lanjut usia ataupun memiliki keterbatasan fisik akan dikembalikan ke keluarga mereka. Kemudian adanya bimbingan mental yang merupakan bagian yang sangat diperlukan untuk menumbuhkan rasa percaya diri yang ada pada diri gelandangan dan pengemis. Pada umumnya mereka memiliki semangat dan potensi yang cukup besar, hanya saja mereka tidak memiliki penyaluran atau sarana penghantar dalam menumbuhkan potensi-potensi yang ada.

\section{f. Pelatihan}

Setelah dilakukan pembinaan oleh pihak Dinas Sosial, maka para gelandangan dan pengemis yang produktif tersebut akan disalurkan kepada UPT Panti Rehabilitasi Sosial Nilam Suri untuk mengikuti proses rehabilitasi atau yang sering kita sebut dengan pelatihan. Hal ini dilakukan untuk meningkatkan kemampuan kerja fisik dan keterampilan yang dibutuhkan. Tetapi jumlah yang dapat mengikuti pelatihan sangat terbatas, sehingga dicari orang yang memang membutuhkan dan diyakinkan dapat mengikuti pelatihan dan memperoleh hasil yang baik. Akhmad Yani sebagai perwakilan dari Dinas Sosial juga menyayangkan tidak adanya panti rehabilitasi yang digunakan untuk melatih secara khusus gelandangan dan pengemis di Kota Batam, melainkan UPT Panti Rehabilitasi Sosial Nilam Suri yang mengatur Penyandang Masalah Kesejahteraan Sosial Kota Batam.

Adanya hambatan dari dana operasional juga menjadi masalah utama dalam hal ini. Untuk melakukan suatu pelatihan membutuhkan dana yang cukup besar karena peserta yang mengikuti pelatihan tidak dipungut oleh biaya apapun. Pihak Panti Rehabilitasi Sosial Nilam Suri telah bekerja sama dengan dua lembaga keterampilan untuk memberikan pelatihan di tempat tersebut. Satu lembaga untuk memberi pelatihan keterampilan perbengkelan dan pengelasan. Satu lainnya, akan memberikan pelatihan menjahit dan menyablon. Materi, bahan, peralatan pelatihan sudah disiapkan oleh lembaga keterampilan tersebut. Pihak panti sudah memiliki ruangan untuk masing-masing keterampilan. Mereka juga memiliki peralatan yang bisa dibilang lengkap.

Tetapi Peneliti sangat menyayangkan sebab Gedung Pusat Rehabilitasi Sosial Nilam Suri yang diresmikan pada tahun 2010 di Nongsa, Batam, Kepulauan Riau itu kurang dimanfaatkan dan tidak terawat sehingga mengalami sejumlah kerusakan. Gedung tersebut tidak dimanfaatkan secara maksimal untuk pelatihan tenaga kerja 
yang tidak memiliki keahlian khusus. Hal ini dikarenakan minimnya dana yang dianggarkan untuk mengadakan suatu pelatihan. Sehingga Gedung besar tersebut tidak dapat digunakan secara maksimal dan pelatihan untuk Penyandang Masalah Kesejahteraan Sosial pun tidak berjalan dengan baik. Alangkah baiknya apabila Pemerintah Kota Batam dapat memberikan solusi yang ampuh sehingga gedung yang sangat luas tersebut bisa termanfaatkan dan tidak sia-sia.

\section{KESIMPULAN DAN SARAN}

\section{Kesimpulan}

Berdasarkan uraian pembahasan yang telah dijelaskan maka Peneliti dapat menarik kesimpulan sebagai berikut:

1. Implementasi dari Peraturan Daerah Kota Batam Nomor 6 Tahun 2002 tentang Ketertban Sosial dalam menangani masalah gelandangan dan pengemis di Kota Batam masih belum terlaksana dengan baik. Ditinjau dari teori efektivitas dinyatakan bahwa kurang efektifnya implementasi dari peraturan daerah tersebut disebabkan oleh faktor dari hukum itu sendiri dimana setiap pasal yang mengatur mengenai gelandangan dan pengemis terlalu umum karena tidak mengupas secara menyeluruh. Kemudian adanya faktor penegak hukum, dimana pengawasan dan upaya penanggulangan yang dilakukan oleh para penegak hukum dinilai masih kurang maksimal. Adanya penyebab lain yaitu faktor sarana atau fasilitas yang tidak sanggup mendukung pelaksanaan penegakan hukum. Selanjutnya faktor masyarakat, yakni rendahnya kesadaran dari masyarakat karena sebagian masyarakat dianggap tidak mendukung peraturan daerah dengan tetap memberikan bantuan kepada para gelandangan dan pengemis di Kota Batam sehingga mempertahankan eksistensi mereka sampai saat ini. Kemudian sanksi pidana perlu diterapkan kepada orang-orang yang melakukan perbuatan menggelandang dan mengemis secara terorganisir, dimana dia dan kelompoknya melakukan perbuatan menggelandang dan mengemis secara sengaja dengan maksud untuk mendapatkan belas kasihan dari masyarakat setempat. Padahal dia dan kelompoknya merupakan orang-orang yang berkecukupan dan masih mampu mendapatkan pekerjaan yang lebih layak.

2. Faktor-faktor yang memengaruhi atau menyebabkan seseorang menjadi gelandangan dan pengemis yaitu faktor ekonomi, faktor pendidikan, faktor urbanisasi, adanya keterbatasan fisik dan faktor sosial budaya. Akar permasalahan yang memengaruhi keberadaan gelandangan dan pengemis adalah kemiskinan. Kemiskinan menyebabkan seseorang tidak dapat memenuhi kebutuhan dasarnya serta kesulitan memperoleh pendidikan dan kesehatan yang layak sehingga ia sulit untuk bersaing di dunia kerja. Tingginya arus urbanisasi juga menimbulkan permasalahan 
karena menyebabkan semakin sempitnya lapangan kerja di Kota Batam. Kemudian kesulitan dalam memperoleh jaminan kesehatan yang layak mengakibatkan beberapa masyarakat mengalami keterbatasan fisik, hal inilah yang memicu keberadaan gelandangan dan pengemis karena mereka yang memiliki keterbatasan fisik tidak mampu bersaing untuk mendapatkan pekerjaan yang layak dan terpaksa untuk menggelandang dan mengemis di jalan umum.

3. Upaya yang telah dilakukan oleh pihak Dinas Sosial Kota Batam dalam menanggulangi gelandangan dan pengemis terdiri dari:

a. Membentuk Tim Pelaksanaan Penjangkauan

b. Melakukan razia secara berskala.

c. Ditangkap dan dibawa ke shelter.

d. Identifikasi.

e. Pembinaan di rumah aman berupa nasehat dan bimbingan mental.

f. Pelatihan.

Pada kenyataannya upaya-upaya yang telah dilakukan tersebut ternyata tidak mampu untuk menanggulangi permasalahan gelandangaan dan pengemis. Adanya proses rehabilitasi sosial yang dijalankan oleh para gelandangan dan pengemis belum membuahkan hasil yang memuaskan, masih banyak gelandangan dan pengemis yang telah mengikuti pelatihan tetapi berakhir kembali ke jalan. Kurangnya tingkat kesadaran diri para peserta pelatihan menjadi salah satu hambatan. Hambatan utama yaitu adanya masalah dana operasional sehingga pelaksanaan proses rehabilitasi tidak maksimal dan tidak adanya panti rehabilitasi yang secara khusus membina gelandangan dan pengemis saja.

\section{Saran}

Berdasarkan Penelitian yang telah dilakukan Peneliti, maka Peneliti ingin memberikan saran beberapa hal, antara lain:

1. Bagi Pemerintah

Untuk menangani keberadaan gelandangan dan pengemis di Kota Batam maka dibutuhkan peraturan yang lebih mengatur secara khusus. Sehingga Peneliti merasa bahwa pihak pemerintah dapat memperbaharui peraturan yang ada sehingga hal-hal yang belum diatur didalamnya dapat dijelaskan secara rinci. Misalnya mengenai sanksi bagi aparat penegak hukum yang melakukan penyimpangan pada saat menangani masalah gelandangan dan pengemis dan juga bagi masyarakat Kota Batam yang tetap memberikan bantuan kepada mereka. Kemudian Pemerintah hendaknya lebih memperhatikan dan mengalokasikan anggaran, tenaga dan sarana yang lebih baik agar peranan Dinas Sosial dalam pembinaan gelandangan dan 
pengemis di Kota Batam dapat dilaksanakan dengan efektif. Sosialisasi terhadap masyarakat Kota Batam juga diperlukan dalam meningkatkan pengetahuan masyarakat mengenai larangan perbuatan gelandangan dan pengemis.

2. Bagi Masyarakat

Untuk menangani masalah gelandangan dan pengemis diperlukan aksi dan dukungan dari masyarakat Kota Batam. Peneliti menganjurkan masyarakat untuk tidak memberi bantuan kepada mereka dalam bentuk apapun. Apabila masyarakat Kota Batam ada yang merasa iba ataupun ingin melakukan suatu kebaikan, maka dianjurkan untuk memberi bantuan dengan cara lain. Misalnya dengan memberikan bantuan kepada panti-panti ataupun sumbangan ke tempat amal dan lain sebagainya. 


\section{Daftar Pustaka}

\section{Buku}

Hartomo, Arnicun, Ilmu Sosial Dasar, Jakarta: PT.Bumi Angkasa, 2001.

Direktorat Pelayanan dan Rehabilitasi Sosial Tuna Sosila, Standar Pelayanan Minimal Pelayanan dan Rehabilitasi Sosial Gelandangan dan Pengemis, Depsos RI, Jakarta, 2005.

\section{Peraturan Perundang-Undangan}

Undang-Undang Dasar Negara Republik Indonesia 1945

Undang-Undang Nomor 24 Tahun 2011 tentang Badan Penyelenggara Jaminan Sosial (Lembaran Negara Republik Indonesia Tahun 2011 Nomor 116, Tambahan Lembaran Negara Republik Indonesia Nomor 5256)

Kitab Undang-Undang Hukum Pidana

Peraturan Daerah Kota Batam Nomor 6 Tahun 2002 Tentang Ketertiban Sosial (Lembaran Daerah Kota Batam Tahun 2002 Nomor 22,Tambahan Lembaran Daerah Kota Batam Tahun 2002 Nomor 6)

\section{Internet}

Batam, BPS kota. "Pengangguran Perkotaan Di Kota Batam," 2017.

"DPRD Batam Sorot Penanganan Gepeng Tak Serius, Kini Pengemis Mulai Marak Di Beberapa Lampu Merah - Tribun Batam." Accessed January 21, 2019. http://batam.tribunnews.com/2019/01/18/dprd-batam-sorotpenanganan-gepeng-tak-serius-kini-pengemis-mulai-marak-dibeberapa-lampu-merah.

"Faktor Ekonomi Jadi Alasan PMKS Meningkat - Heibogor.com." Accessed February 23, 2019. http://www.heibogor.com/post/detail/47515/faktor-ekonomi-jadialasan-pmks-meningkat/.

"Jumlah Pencari Kerja Asal Luar Batam Ternyata Banyak, Jumlahnya Mencapai 25 Ribu Lebih - Tribun Batam.” Accessed February 21, 2019. http://batam.tribunnews.com/2018/09/18/jumlah-pencarikerja-asal-luar-batam-ternyata-banyak-jumlahnya-mencapai-25ribu-lebih.

"Metode Penelitian Hukum Empiris Dan Normatif." Accessed March 20, 2019. https://idtesis.com/metode-penelitian-hukum-empiris-dannormatif/.

"Teknik Pengumpulan Data Dan Analisis Dalam Penelitian Fatkhan.web.id." Accessed March 20, 2019. https://fatkhan.web.id/teknik-pengumpulan-data-dan-analisisdalam-penelitian/. 